\title{
ПОИСК ГЕНОТИПОВ РЖИ И ПШЕНИЦЫ, УСТОЙЧИВЫХ К Claviceps purpurea (Fr.) Tul. И НЕ НАКАПЛИВАЮЩИХ ЭРГОАЛКАЛОИДЫ В СКЛЕРОЦИЯХ ГРИБА
}

\author{
Т.К. ШЕШЕГОВА ${ }^{\circledR}$, Л.М. ЩЕКЛЕИНА 1 , Т.В. АНТИПОВА ${ }^{2}$, \\ В.П. ЖЕЛИФОНОВА², А.Г. КОЗЛОВСКИЙ²
}

Спорынья зерновых культур, вызываемая грибом Claviceps purpurea (Fr.) Tul., - прогрессирующее заболевание ржи и пшеницы. Создание устойчивых сортов - один из эффективных способов решения этой сложной проблемы. В настоящей работе мы впервые установили состав и содержание эргоалкалоидов (ЭА) в склероциях кировской популяции C. purpurea. Показана слабая положительная связь между суммарным содержанием ЭА в склероциях (токсичность) и поражением 100 новых сортов ржи и пшеницы спорыньей (патогенность). Для селекции этих культур выявлены эффективные генетические источники, сочетающие устойчивость к поражению грибом $C$. purpurea и сниженное накоплению ЭА в образуемых на растениях склероциях гриба. Цель работы - определение суммарного содержания и состава эргоалкалоидов в склероциях $C$. purpurea, собранных с озимой ржи и яровой мягкой пшеницы в Кировской области, и выявление генотипов, у которых проявляется устойчивость к спорынье и в склероциях не накапливаются ЭА гриба. Полевые исследования проводили в ФГБНУ Федеральный аграрный научный центр Северо-Востока им. Н.В. Рудницкого (ФАНЦ Северо-Востока) в 2017-2019 годах. Материалом служили 26 новых диплоидных $(\times 2)$ сортов озимой ржи (Secale cereale L.) и 20 сортов яровой мягкой пшеницы (Triticum aestivum L.) селекции ФАНЦ Северо-Востока, а также 34 и 20 образцов этих культур из мировой коллекции ФИЦ Всероссийский институт генетических ресурсов растений им. Н.И. Вавилова (ВИР). Растения инокулировали водной суспензией конидий $C$. purpurea. Использовали природные изоляты конидий патогена, выделенные из свежесобранных на территории Кировской области склероциев ржи и пшеницы. Концентрация спор в инокуляте $3 \times 10^{6}$ кониций/мл. Инокулировали по 10-15 растений в 3-кратной повторности. Для характеристики сортов использовали два показателя: поражение (доля растений со склероциями в выборке, \%) и засоренность зерна склероциями (содержание склероциев в зерновой пробе, \% по массе). Отобранные склероции использовали для биометрических исследований (масса, крупность) и анализа ЭА. Устойчивость сортов к спорынье оценивали на основании шкалы Т. Miedaner с соавторами. Содержание ЭА и их состав в склероциях кировской популяции гриба $C$. purpurea определяли в ФИЦ ПНЦ БИ РАН Институте биохимии и физиологии микроорганизмов им. Г.К. Скрябина РАН (г. Пущино). Анализ экстрактов осуществляли методом тонкослойной хроматографии (ТCX) на пластинках силикагеля (Silica gel F254, «Merck», Германия). ЭА обнаруживали по поглощению или флуоресценции в УФ-свете $(\lambda=264$ нм) и после опрыскивания пластин реактивом Эрлиха. Метаболиты идентифицировали методом тонкослойной хроматографии со стандартными образцами и с помощью данных УФ-спектроскопии и масс-спектрометрии. Суммарное содержание ЭА в экстрактах определяли спектрофотометрически при $\lambda=313$ нм. Установлено, что тестируемый генофонд был в основном восприимчив к спорынье. У пшеницы выявили два иммунных сорта (Новосибирская 18 и новая линия Т-66) и 13 - относительно устойчивых с поражением не более 5,2 $\%$ и примесью склероциев в зерне не более $0,3 \%$, в то время как у наиболее восприимчивого (индикаторного) сорта эти показатели составили 21,7 и 1,5\%. У озимой ржи иммунные формы отсутствовали, а у 10 сортов поражение варьировало от 5,8 до 33,0 \%, засоренность зерна склероциями - от 0,3 до $1,4 \%$ (у индикаторного сорта соответственно 100 и 37,0\%). У 30 различных по восприимчивости к спорынье сортов ржи и пшеницы проанализирован состав и содержание ЭА в склероциях гриба $C$. purpurea. Состав ЭА был одинаковым и состоял из эргокристина, эрготамина и его стереоизомера эрготаминина. Только у казахстанского сорта пшеницы Самгау был идентифицирован один эрготамин. В склероциях, собранных с растений ржи, количество ЭА изменялось от 0 до 0,36 \% от их массы, с пшеницы - от 0 до 2,40\%. Обнаружено, что 9 новых популяций ржи селекции ФАНЦ Северо-Востока и 4 сорта пшеницы не накапливали ЭА. Выявлена слабая отрицательная зависимость $(p=0,05)$ между массой одного склероция и накоплением ЭА: у озимой ржи $r=-0,46$, у яровой пшеницы $r=-0,32$. Не установлено значимой связи между токсичностью и патогенностью гриба $C$. purpurea, о чем свидетельствует коэффициент корреляции между поражением спорыньей и содержанием ЭА у ржи, который составил $r=0,22(p=0,05)$. Тем не менее информация о содержании ЭА важна для поиска иммунологически и селекционно ценных генотипов, сочетающих устойчивость к поражению спорыньей со способностью подавлять накопление ЭА. Этим свойством выделились немецкий сорт пшеницы Еpos и новые популяции ржи Румба, Гармония и Симфония.

Ключевые слова: озимая рожь, яровая пшеница, спорынья, склероции Claviceps purpurea, устойчивые сорта, эргоалкалоиды, токсичность, патогенность. 
Спорынья зерновых культур, вызываемая грибом Claviceps purpurea (Fr.) Tul. (класс Ascomycetes), в последние годы прогрессирует во многих регионах Российской Федерации $(1,2)$ и за рубежом, особенно в республиках Прибалтики, западных областях Белоруссии, в Центральной Европе (35). Так, в Германии увеличение пораженности растений $C$. purpurea обусловлено возрастающей долей в структуре посевов высокоурожайной, но более восприимчивой гибридной ржи (6). В Беларуси особое беспокойство вызывает наличие склероциев в партиях зернофуража, поскольку их форма и размер идентичны зерновке ржи, а эффективность очистки зерновой массы не превышает $23 \%$ (7).

Расширение ареала и вредоносность болезни обусловлены комплексом причин. Определенную опасность представляют неиспользуемые земли сельскохозяйственного назначения, в которых сохраняются и накапливаются инфекционные структуры $C$. purpurea. Много вопросов остается и к современным технологиям возделывания культур, направленным на минимизацию обработки почвы и других технологических процессов. В условиях нестабильности климата усиливается негативное влияние антропогенных и техногенных факторов на полевые биоценозы. В Кировской области $C$. purpurea ежегодно инфицирует растения на половине посевной площади озимых зерновых культур. Доля таких растений в биоценозах ржи варьирует от 0,2 до $5,0 \%(8,9)$. Современные технологии производства зерна не обеспечивают полной защиты от спорыньи и попадания склероциев в семенной материал.

В связи с ужесточением отечественных ГОСТов и зарубежных регламентов, не допускающих наличия склероциев в семенах высших репродукций $(4,6,10)$, контроль распространения болезни имеет важное значения для обеспечения качества и безопасности продукции. Использование зерна и кормов с примесью склероциев может вызвать отравление человека и животных (11-14). Так, по данным канадских ученых (15), при крайне низком $(0,004 \%)$ количестве склероциев в партиях зерна пшеницы в ее муке выявляется до шести типов эргоалкалоидов (ЭА). Согласно результатам других исследователей (16), алкалоиды спорыньи очень стабильны при приготовлении различных продуктов питания из такой муки. Хотя способность патогена $C$. purpurea продуцировать ЭА генетически детерминирована, их количество и состав зависят от растения-хозяина, географических и климатических факторов $(6,17-20)$. Наиболее распространены эргометрин, эрготамин, эргокорнин, эргокриптин, эргозин и эргокристин $(21,22)$.

Методы генетической защиты зерновых культур от спорыньи в Российской Федерации до сих пор не разработаны, хотя отдельные исследования проводятся в Татарском НИИСХ ФИЦ КНЦ РАН (г. Казань) и ФГБНУ ФИЦ Немчиновка (Московская обл.). Генофонд основных продовольственных культур - озимой ржи и яровой пшеницы практически не изучен по устойчивости к спорынье, особенно в условиях искусственной инокуляции растений. Недостаточно информации о биохимических и иных механизмах устойчивости к C. purpurea, а также данных по составу и содержанию ЭА в склероциях разных зерновых культур, что отчасти ограничивает прогресс в их селекции на устойчивость к спорынье.

Селекционно-генетические исследования в патосистеме Secale sereale L.-C. purpurea затрудняет сложная биология возбудителя и процедура моделирования инфекционного фона, необходимого для поиска и создания доноров устойчивости, отсутствие информации о фенотипической и генетической структуре популяций рода Claviceps и биохимических маркерах устойчивости. Важный биомаркер, который активно используется в Германии, - 
повышенное пыльцеобразование и фертильность пыльцы (23). В связи со значительным влиянием среды на патогенез в системе $S$. sereale-C. purpurea исследователи отмечают, что для достоверной оценки генотипа по отношению к спорынье необходимо его повторное тестирование (23).

В настоящей работе мы впервые установлен состав и содержание ЭА в кировской популяции гриба $C$. purpurea. Показана слабая положительная связь между суммарным содержанием ЭА в склероциях (токсичность) и поражением 100 новых сортов ржи и пшеницы спорыньей (патогенность). Для селекции этих культур выявлены эффективные генетические источники сочетанной устойчивости к поражению растений и накоплению ЭА в зерне.

Цель работы - определение суммарного содержания и состава эргоалкалоидов в склероциях Claviceps purpurea, собранных с озимой ржи и яровой мягкой пшеницы в Кировской области, и выявление генотипов этих культур, устойчивых к спорынье и накоплению ЭА.

Методика. Полевые исследования проводили в ФГБНУ Федеральный аграрный научный центр Северо-Востока им. Н.В. Рудницкого (ФАНЦ Северо-Востока) в 2017-2019 годах. Материалом служили 26 новых диплоидных $(\times 2)$ сортов озимой ржи (Secale cereale L.) и 20 сортов яровой мягкой пшеницы (Triticum aestivum L.) селекции ФАНЦ Северо-Востока, а также 34 и 20 образцов этих культур из мировой коллекции ВИР (ФИЦ Всероссийский институт генетических ресурсов растений им. Н.И. Вавилова) (24). Генофонд изучали на инфекционном участке при инокуляции растений водной суспензией конидий $C$. purpurea. Использовали природные изоляты конидий патогена, выделенные из свежесобранных на территории Кировской области склероциев на растениях ржи и пшеницы и хранящиеся на картофельно-глюкозном агаре в рабочей коллекции ФАНЦ СевероВостока. Инокулированные растения сравнивали с контрольными (без инфекции С. purpurea).

Инокулюм готовили непосредственно перед заражением, споры смывали с поверхности чистой культуры патогена дистиллированной водой. Необходимую концентрацию $\left(3 \times 10^{6}\right.$ конидий/мл) устанавливали с помощью камеры Горяева (25). Инокулюм шприцом вносили в завязь в период от колошения до начала цветения (фазы 55-61 по шкале Zadoks). Инокулировали по 10-15 растений в 3-кратной повторности. Для характеристики сортов использовали два показателя: поражение (доля растений со склероциями в выборке, \%) и засоренность зерна склероциями (содержание склероциев в зерновой пробе, \% по массе). Для этого после обмолота инокулированных растений отделяли все склероции от зерна, взвешивали и рассчитывали отношение их массы к массе зерна. Собранные склероции использовали для биометрических исследований (масса, крупность) и анализа ЭА. Устойчивость сортов к спорынье оценивали по шкале Т. Miedaner с соавт. (26), согласно которой при поражении до 0,5 \% и наличии склероциев в выборке не более 0,01 \% от массы зерна сорт характеризуется как высокоустойчивый, при показателях соответственно до 1,5\% и до 0,10\% - как среднеустойчивый, при более 3,0 \% и до $0,3 \%$ - как восприимчивый.

У 30 различных по восприимчивости к спорынье сортов ржи и пшеницы определяли состав и содержание ЭА в склероциях гриба C. purpurea (ФИЦ ПНЦБИ РАН, Институт биохимии и физиологии микроорганизмов им. Г.К. Скрябина РАН, г. Пущино). ЭА извлекали из 1 г измельченных склероциев двумя способами. В первом опыте образцы экстрагировали трижды 50 \% водным раствором ацетона, содержащим $\mathrm{H}_{2} \mathrm{SO}_{4}$ для создания кислой среды (рН 4,5). Объединенный экстракт концентрировали на роторном испарителе ИР-1М2, («Химлаборприбор», Россия) до половины 
первоначального объема. В полученную водную фракцию вносили $25 \%$ раствор аммиака до рН 9-10 и экстрагировали 3 раза хлороформом. Хлороформные экстракты подсушивали безводным $\mathrm{Na}_{2} \mathrm{SO}_{4}$ и упаривали на роторном испарителе. Второй метод заключался в экстракции ЭА смесью хлороформа и метанола в соотношении 1:1.

Экстракты анализировали методом тонкослойной хроматографии (TCX) на пластинках силикагеля (Silica gel F254, «Merck», Германия) в системах хлороформ:метанол:25\% $\mathrm{NH}_{4} \mathrm{OH}$ в соотношении 90:10:0,1 (I) и 80:20:0,2 (II). ЭА обнаруживали по поглощению или флуоресценции в УФсвете $(\lambda=264$ нм) и после опрыскивания пластин реактивом Эрлиха. ЭА выделяли и очищали препаративной ТСX на пластинах силикагеля. Метаболиты идентифицировали посредством хроматографии со стандартными образцами и с помощью данных УФ-спектроскопии и масс-спектрометрии. УФ-спектры соединений получали на спектрофотометре UV-160A («Shimadzu», Япония). Масс-спектры соединений регистрировали на квадрупольном масс-спектрометре LCQ Advantage MAX («Thermo Finnigan», Германия), используя одноканальный шприцевой насос для прямого ввода образца в камеру для химической ионизации при атмосферном давлении. Содержание суммарного количества ЭА в экстрактах определяли спектрофотометрически в метаноле при $\lambda=313$ нм. Расчет вели, используя коэффициент молярной экстинкции эрготамина $(\log \varepsilon=3,86)$. Измерения для каждого образца экстракта проводили не менее 5 раз.

Статистическую обработку результатов осуществляли методами дисперсионного и корреляционного анализа. В матрицу расчетов вносили данные по поражению сортов и засоренности зерна склероциями и устанавливали достоверность различий по отношению к сортам-стандартам ржи (Фаленская 4) и пшеницы (Баженка). Использовали пакет программ статистического и биометрико-генетического анализа в растениеводстве и селекции AGROS (версия 2.07) и программу Microsoft Office Excel. Содержание ЭА представлено в виде среднего арифметического значения $(M)$. Доверительные интервалы для ЭА $( \pm \mathrm{SEM})$ не превышали $\pm 5 \%(\mathrm{p} \leq 0,05)$.

Результаты. Тестируемые сорта ржи и пшеницы в контроле не имели симптомов болезни или на них встречались единичные склероции. При искусственной инокуляции сортимент ранжировался от иммунных до восприимчивых форм. У новых диплоидных $(\times 2)$ популяций ржи селекции ФАНЦ Северо-Востока поражение варьировало от 14,2 (Леда) до 78,5 \% (Ниоба), у диплоидных образцов из коллекции ВИР - от 5,8 (Подарок НП) до $100 \%$ (Беняконская 2, Гетера 2); засоренность зерна склероциями изменялась соответственно от 0,6 (Леда) до 7,6 \% (Грация) и от 0,3 (Подарок НП) до 37,0 \% (Компус). В таблице 1 представлены наименее поражаемые в течение 3 лет изучения и иммунологически ценные для селекции сорта ржи.

T. Miedaner с соавт. $(6,26)$ установили, что среди четырех групп растений ржи (популяционные, гибридные, синтетические и гибриды) популяционные сорта оказались в 2 раза устойчивее к спорынье. У наименее поражаемого популяционного сорта засоренность зерна склероциями составила $0,37 \%$, у гибрида - 0,89 \%. Установлено также отсутствие значимых различий по составу ЭА (26). Наиболее распространенными алкалоидами были эргозин, эргокристин и эрготамин. Однако их общее содержание имело достоверную генотипическую вариабельность. Фенотипическое проявление признака также связано с плоидностью генотипа, о чем свидетельствуют исследования Э. Урбана с соавт. (3). По данным авторов, восприимчивее к спорынье тетраплоидные $(\times 4)$ генотипы, имеющие более продолжительный, чем у диплоидных сортов $(\times 2)$, период открытого цветения. 
Можно полагать, что диплоидные популяции ржи перспективнее в этом направлении селекции. В настоящее время в Российской Федерации в Государственный реестр селекционных достижений, допущенных к использованию, включены 109 сортов озимой ржи, но имеется лишь 10 гибридов и 9 сортов тетраплоидного типа, остальные - диплоидные. В Германии, наоборот, около двух третей всех посевных площадей ржи занято гибридами (26).

1. Иммунологически ценные сорта озимой ржи (Secale cereale L.) и яровой мягкой пшеницы (Triticum aestivum L.), устойчивые к Claviceps purpurea (Fr.) Tul. (M士SEM; искусственная инокуляция, г. Киров, 2017-2019 годы)

\begin{tabular}{|c|c|c|}
\hline Сорт, линия, происхождение & Поражение спорыньей, \% & $\begin{array}{l}\text { Засоренность зерна } \\
\text { склероциями, \% }\end{array}$ \\
\hline \multicolumn{3}{|c|}{$\begin{array}{c}\text { О з и м а я ро ж ь } \\
\text { Сорта из коллекции ВИР }\end{array}$} \\
\hline Подарок НП, Ленинградская область & $5,8 \pm 0,50^{*}$ & $0,3 \pm 0,02 *$ \\
\hline Чулпан 2, Ленинградская область & $14,2 \pm 2,80^{*}$ & $0,6 \pm 0,08^{*}$ \\
\hline Вавиловская НП, Ленинградская область & $15,3 \pm 2,90^{*}$ & $1,0 \pm 0,09^{*}$ \\
\hline Россиянка 2, Ленинградская область & $17,6 \pm 3,10^{*}$ & $0,9 \pm 0,25^{*}$ \\
\hline \multicolumn{3}{|l|}{ Тринодис 4 - Минвак-139/09 НП, } \\
\hline Ленинградская область & $16,6 \pm 2,80^{*}$ & $0,6 \pm 0,09^{*}$ \\
\hline \multicolumn{3}{|l|}{ Красноярская универсальная НП, } \\
\hline Ленинградская область & $18,7 \pm 3,90^{*}$ & $0,8 \pm 0,19^{*}$ \\
\hline Среднее по сортименту & 46,6 & 4,9 \\
\hline \multicolumn{3}{|c|}{ Сорта селекции ФГБНУ Федеральный аграрный научный центр Северо-Востока им. Н.В. Рудницкого } \\
\hline Леда & $14,2 \pm 2,80^{*}$ & $0,6 \pm 0,08^{*}$ \\
\hline Симфония & $19,5 \pm 4,20^{*}$ & $1,2 \pm 0,28^{*}$ \\
\hline Гармония & $30,7 \pm 5,70^{*}$ & $1,2 \pm 0,29 *$ \\
\hline Румба & $33,0 \pm 6,40^{*}$ & $1,4 \pm 0,31^{*}$ \\
\hline Фаленская 4 (стандарт) & $40,7 \pm 8,20$ & $3,5 \pm 0,75$ \\
\hline Среднее по сортименту & 57,4 & 3,6 \\
\hline Беняконская 2 (индикаторный сорт) & 100 & $20,0 \pm 6,80$ \\
\hline Компус (индикаторный сорт) & $50,0 \pm 8,80$ & $37,0 \pm 9,90$ \\
\hline \multicolumn{3}{|c|}{$\begin{array}{c}\text { Я ров а я м ягк а я п ше н и ц а } \\
\text { Сорта из коллекции ВИР }\end{array}$} \\
\hline Новосибирская 18 , Новосибирская область & $0^{*}$ & $0^{*}$ \\
\hline Тулайковская надежда, Самарская область & $1,3 \pm 0,11^{*}$ & $0,1 \pm 0,01^{*}$ \\
\hline Кайыр, Казахстан & $1,3 \pm 0,11^{*}$ & $0,1 \pm 0,01^{*}$ \\
\hline U1 Alta Blanca, США & $1,6 \pm 0,18^{*}$ & $0,1 \pm 0,01^{*}$ \\
\hline Epos, Германия & $2,1 \pm 0,52^{*}$ & $0,2 \pm 0,03^{*}$ \\
\hline Самгау, Казахстан & $2,5 \pm 0,50^{*}$ & $0,2 \pm 0,03^{*}$ \\
\hline Среднее по сортименту & 3,7 & 0,2 \\
\hline \multicolumn{3}{|c|}{ Сорта селекции ФГБНУ Федеральный аграрный научный центр Северо-Востока им. Н.В. Рудницкого } \\
\hline T-66 & $0^{*}$ & $0^{*}$ \\
\hline C-65 & $1,7 \pm 0,16^{*}$ & $0,1 \pm 0,01^{*}$ \\
\hline У-80 & $2,9 \pm 0,80^{*}$ & $0,1 \pm 0,01^{*}$ \\
\hline $\mathrm{y}-28$ & $4,7 \pm 0,95^{*}$ & $0,2 \pm 0,03^{*}$ \\
\hline $\mathrm{C}-84$ & $5,1 \pm 1,00^{*}$ & $0,2 \pm 0,03^{*}$ \\
\hline $\mathrm{T}-123$ & $5,1 \pm 1,01^{*}$ & $0,2 \pm 0,03^{*}$ \\
\hline $\mathrm{T}-141$ & $5,2 \pm 1,00^{*}$ & $0,3 \pm 0,05$ \\
\hline Баженка (стандарт) & $7,4 \pm 1,45$ & $0,4 \pm 0,15$ \\
\hline Среднее по сортименту & 8,1 & 0,27 \\
\hline П-57 (индикаторный сорт) & $21,7 \pm 4,40$ & $1,5 \pm 0,80$ \\
\hline
\end{tabular}

П р и м е ч а н и е. НП - низкопентозановые сорта.

* Различия со стандартом (сорт Фаленская 4 для озимой ржи и сорт Баженка - для яровой мягкой пшеницы) статистически значимы при $\mathrm{P} \geq 0,95$.

Резистентность яровой пшеницы к спорынье, которая обусловлена преимущественно непродолжительным и закрытым типом цветения растений, была значительно выше (25). Тем не менее, как и у ржи, отмечали значительную изменчивость иммунологических показателей (см. табл. 1). У сортов селекции ФАНЦ Северо-Востока поражение варьировало от 0 (Т66) до 21,7 \% (П-57) при засоренности зерна склероциями от 0 (Т-66) до $1,5 \%$ (П-57); у коллекционных образцов соответственно от 0 (Новосибирская 18) до 13,9 \% (ЛТ-3) и от 0 (Новосибирская 18) до 1,3 \% (ЛТ-3). У сорта Новосибирская 18 и новой линии Т-66 не сформировались склероции при искусственной инокуляции растений $C$. purpurea (см. табл. 1). Отсутствие склероциев могло быть детерминировано генами, контролирую- 
щими физиологические механизмы устойчивости. Так, сорт Новосибирская 18 характеризовался быстрым развитием в первой половине онтогенеза (от всходов до цветения, фазы 10-69 по шкале Zadoks), и относился к группе раннеспелых. Устойчивость линии Т-66, вероятно, была обусловлена ее короткостебельностью и прочностью соломины, вследствие чего она не полегала, обеспечивая хорошее пыльцеобразование. К среднеустойчивым можно отнести сорта Тулайковская надежда и Кайыр.

2. Содержание эргоалкалоидов и их состав в склероциях Claviceps purpurea (Fr.) Tul. у разных по восприимчивости к спорынье сортов озимой ржи (Secale

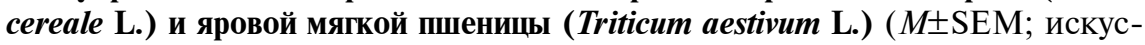
ственная инокуляция, г. Киров, 2017-2019 годы)

\begin{tabular}{|c|c|c|c|}
\hline \multirow{2}{*}{ Сорт, линия } & \multirow{2}{*}{ Происхождение } & \multicolumn{2}{|c|}{ Эргоалкалоиды } \\
\hline & & от массы склероциев, \% & состав \\
\hline \multicolumn{4}{|c|}{ Озим а я рожь } \\
\hline Вятка 2 & Кировская область & $0,22 \pm 0,009$ & ЭТ, ЭМ, ЭК \\
\hline Фаленская 4 & & $0,14 \pm 0,007$ & ЭТ, ЭМ, ЭК \\
\hline Грация & & $0,10 \pm 0,004$ & ЭТ, ЭМ, ЭК \\
\hline Графит & & 0 & \\
\hline Перепел & & 0 & \\
\hline Румба & & 0 & \\
\hline Гармония & & 0 & \\
\hline Симфония & & 0 & \\
\hline Триумф & & $0,04 \pm 0,002$ & ЭТ, ЭМ, ЭК \\
\hline Ниоба & & 0 & \\
\hline Леда & & $0,17 \pm 0,008$ & ЭТ, ЭМ, ЭК \\
\hline Садко & & 0 & \\
\hline Poca & & 0 & \\
\hline Capa & & 0 & \\
\hline Амило 2 & Ленинградская область & $0,14 \pm 0,006$ & ЭТ, ЭМ, ЭК \\
\hline Янтарная НП & & $0,07 \pm 0,009$ & ЭТ, ЭМ, ЭК \\
\hline Подарок НП & & $0,20 \pm 0,010$ & ЭТ, ЭМ, ЭК \\
\hline Вавиловская НП & & $0,06 \pm 0,002$ & ЭТ, ЭМ, ЭК \\
\hline Рушник 2 НП & & $0,36 \pm 0,015$ & ЭТ, ЭМ, ЭК \\
\hline \multirow[t]{2}{*}{ Берегиня НП } & & $0,06 \pm 0,002$ & ЭТ, ЭМ, ЭК \\
\hline & Яровая мягкая & я я пше ни ц а & \\
\hline H-154 & Кировская область & 0 & \\
\hline$\Pi-57$ & & $0,06 \pm 0,002$ & ЭТ, ЭМ, ЭК \\
\hline C-84 & & $0,09 \pm 0,004$ & ЭТ, ЭМ, ЭК \\
\hline T-38 & & 0 & \\
\hline T-79 & & $0,24 \pm 0,011$ & ЭТ, ЭМ, ЭК \\
\hline Оренбургская 23 & Оренбургская область & 0 & \\
\hline ЛТ-3 & Ленинградская область & $0,12 \pm 0,005$ & ЭТ, ЭМ, ЭК \\
\hline Самгау & Казахстан & $0,14 \pm 0,006$ & ЭТ \\
\hline Epos & Германия & 0 & \\
\hline Long Chan & Китай & $0,12 \pm 0,004$ & ЭТ, ЭМ, ЭК \\
\hline
\end{tabular}

Среди изученного генофонда озимой ржи и яровой мягкой пшеницы лучшее иммунологическое состояние по отношению к спорынье отмечали у коллекционных образцов, созданных в России и за рубежом, по сравнению с сортами селекции ФАНЦ Северо-Востока. Выделенные на жестком инфекционном фоне иммунные и менее поражаемые сорта этих культур могут быть использованы как источники признака для селекции.

Выявлена значительная вариабельность биометрических признаков склероциев у разных сортов ржи и пшеницы. Так, масса одного склероция у ржи изменялась от 0,05 (Берегиня НП) до 0,34 г (Графит), а в среднем у коллекционных сортов составила 0,10 г, у сортов селекции ФАНЦ СевероВостока - 0,20 г. У яровой пшеницы наиболее мелкие склероции $(0,06$ г) были у китайского сорта Long Chun 7, крупные $(0,15$ г) - у линии Н-154. Как у ржи, так и у пшеницы наиболее крупные склероции сформировались у сортов селекции ФАНЦ Северо-Востока.

При анализе было установлено отсутствие ЭА в 9 из 20 образцов склероциев, собранных с растений озимой ржи, и в 4 из $10-$ с яровой 
пшеницы (табл. 2).

В остальных образцах содержание ЭА различалось в значительных пределах. Количество ЭА в ржаных склероциях изменялось от 0,04 (Триумф) до $0,36 \%$ (Рушник 2 НП) от их массы, в пшеничных - от 0,60 (линия П-57) до 0,24 \% (линия Т-79). В наших более ранних исследованиях (9) суммарное содержание ЭА в склероциях ржи достигало 0,90\%, что может быть обусловлено избыточным увлажнением в период формирования склероциев. На тесную связь между климатическими факторами, содержанием и составом ЭА также обращали внимание Т. Miedaner с соавт. (6). В. Oeser с соавт. (18) отмечают, что с учетом широкой филогенетической специализации биотрофного патогена $C$. purpurea обоснованно применение разных его штаммов, изолированных из зерновых таксонов.

Корреляционный анализа выявил отрицательную связь $(\mathrm{p}=0,05)$ между суммарной массой склероциев и содержанием ЭА, которая у сортов ржи составила $r=-0,46$, у пшеницы $-r=-0,32$. Однако эта важная с практической точки зрения тенденция требует дополнительного доказательства статистическими методами. Учитывая, что мелкие склероции невозможно полностью отделить от зернового вороха при механической сортировке и часть их попадает в семенные и продовольственные партии зерна (27-29), опасность этой фракции представляется наиболее серьезной. В свою очередь, на засоренность зерна ржи склероциями существенное (при $\mathrm{p}=0,05)$ влияние оказывало поражение сортов спорыньей $(r=0,70)$ и масса самих склероциев $(r=0,69)$.

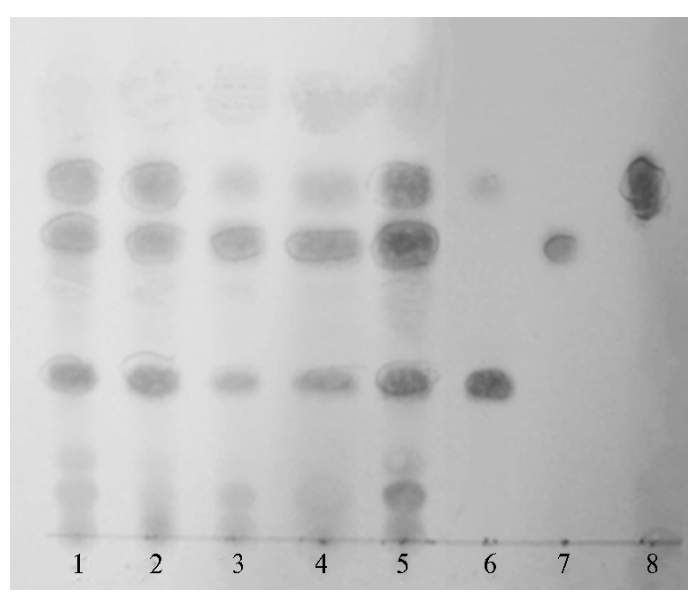

Тонкослойная хроматография экстрактов из собранных на разных сортах озимой ржи (Secale cereale L.) склероциев после опрыскивания реактивом Эрлиха: 1 - Амило 2, 2 - Янтарная НП, 3 - Подарок НП, 4 - Вавиловская НП, 5 - Рушник 2 НП, 6, 7 и 8 - стандарты соответственно эрготамина, эргокристина и эрготаминина. Пластинки силикагеля (Silica gel F254, «Merck», Германия) в системе хлороформ:метанол:25\% NH4OH (90:10:0,1).
В 17 изученных образцах склероциев были обнаружены метаболиты 1 и 2, мигрирующие при TCX с Rf $=0,21$ (I) и Rf $=0,49$ (II), которые флуоресцировали в УФсвете $(\lambda=254$ нм) и давали фиолетовое окрашивание с реактивом Эрлиха. Масс-спектры метаболитов были идентичны и имели отрицательный молекулярный ион $580[\mathrm{M}-\mathrm{H}]^{-}$. Хроматографическая подвижность и МС/МС спектр метаболита 1 совпадал со стандартом эрготамина, а метаболита 2 со стандартом эрготаминина. На основании полученных данных метаболиты 1 и 2 были идентифицированы как пептидные эргоалкалоиды эрготамин и его стереоизомер эрготаминин. В этих же образцах склероциев был обнаружен метаболит 3, мигрирующий при TCX Rf = 0,41 (I), который также флуоресцировал и давал фиолетовое окрашивание с реактивом Эрлиха. МС/МС метаболита 3 имел отрицательный молекулярный ион 608 [M-H] $]^{-}$. Хроматографическая подвижность и МС/МС спектр метаболита 3 совпадали со стандартом эргокристина. На основании полученных данных он был идентифицирован как эргокристин (рис.). 
В наших исследованиях коэффициент корреляции между поражением растений спорыньей и суммарным содержанием ЭА у ржи составил $r=0,22$ $(\mathrm{p}=0,05)$, что косвенно свидетельствует об отсутствии значимой связи между токсичностью и патогенностью гриба C. purpurea. Тем не менее информация о содержании эргоалкалоидов важна для поиска генотипов зерновых культур с наименьшим накоплением ЭА в склероциях. В этом случае они представляют собой менее опасную механическую примесь в зерновой массе. Наибольшую селекционно-иммунологическую ценность имеют сорта, сочетающие устойчивость к поражению спорыньей и накоплению ЭА. Среди них немецкий сорт яровой пшеницы Epos и новые популяции озимой ржи Симфония, Гармония и Румба. Следует отметить, что высокоурожайный, устойчивый к спорынье сорт Румба подготовлен к передаче на государственное испытание, а популяция Гармония получена с использованием источников устойчивости к спорынье и фузариозу колоса (1).

Таким образом, мы проанализировали состав и содержание эргоалкалоидов (ЭА) в склероциях, выявленных в условиях искусственной инокуляции растений грибом Claviceps purpurea у различных по восприимчивости к спорынье сортов ржи и пшеницы. У 5 сортов пшеницы и 11 сортов ржи состав ЭА представлен эргокристином, эрготамином и его стереоизомером эрготаминином. У казахстанского сорта пшеницы Самгау идентифицирован только эрготамин. Содержание ЭА в исследуемых образцах различалось в значительных пределах. Сорта озимой ржи и яровой пшеницы, у которых в склероциях не накапливаются ЭА, имеют практическую значимость, поскольку засоренность продовольственного и фуражного зерна такими склероциями биологически не опасно. Особую селекционную ценность представляют генотипы, у которых устойчивость к поражению спорыньей сочетается с отсутствием накопления ЭА в склероциях. Этим свойством характеризуются сорта озимой ржи Румба, Симфония, Гармония и яровой пшеницы Epos, которые могут быть использованы в селекции в качестве источников признака.

Авторы выражают благодарность Б.П. Баскунову (Институт биохимии и физиологии микроорганизмов им. Г.К. Скрябина РАН - обособленное подразделение ФГБУН ФИЦ «Пущинский научный центр биологических исследований РАН») за масс-спектрометрические данные.

\section{ЛИТЕРАТУРА}

1. Пономарева М.Л., Пономарев С.Н., Маннапова, Г.С., Илалова, Л.В. Фитосанитарный мониторинг наиболее вредоносных болезней озимой ржи в республике Татарстан. Вестник Красноярского государственного аграрного университета, 2019, 9(150): 27-34.

2. Щеклеина Л.М. Влияние погодных факторов на отдельные периоды развития гриба Claviceps purpurea (Fr.) Tul и уровень вредоносности спорыньи в Кировской области. Аграрная наука Евро-Северо-Востока, 2019, 20(2): 134- 143 (doi: 10.30766/2072-9081.2019.20.2.134-143).

3. Урбан Э., Гордей С. Получение дигаплоидов ржи с использованием культуры пыльников in vitro. Наука и инновации, 2018, 5(83): 77-80.

4. Немкович А.И. Спорынья злаковых культур. Защита и карантин растений, 2006, 6: 25-26.

5. Кадыров А.М. Изучение устойчивости ярового ячменя к поражению спорыньей ( $C$. ригригеа). Земледелие и селекция в Белоруссии, 2003, 39: 225-229.

6. Miedaner T., Geiger H.H. Biology, genetics and manogement of ergot (Claviceps spp.) in rye, sorghum and pearl mille. Toxins, 2015, 7(3): 659-678 (doi: 10.3390/toxins7030659).

7. Хоченков А.А., Ходосовский Д.Н., Соляник В.В., Безмен В.А. Роль стандартов на зернофураж в обеспечении производства экологически чистой продукции животноводства. Известия Академии аграрных наук Республики Беларусь, 2000, 3: 74-77.

8. Шеклеина Л.М., Шешегова Т.К. Болезни Secale cereale L. в Кировской области и генетические источники устойчивости для селекции. Вестник Красноярского ГАУ, 2020, 6: 86-92 (doi: 10.36718/1819-4036-2020-6-86-92).

9. Шешегова Т.К., Щеклеина Л.М., Желифонова В.П., Антипова Т.В., Баскунов Б.П., 
Козловский А.Г. Устойчивость сортов ржи к спорынье и содержание эргоалкалоидов в склероциях Claviceps purpurea в условиях Кировской области. Микология и фитопатология, 2019, 53(3): 177-182 (doi: 10.1134/S0026364819030127).

10. Гончаренко А.А. Современное состояние производства, методы и перспективные направления селекции озимой ржи в РФ. Мат. Всерос. науч.-практ. конф. «Озимая рожь: селекция, семеноводство, технологии и переработка». Уфа, 2009: 40-76.

11. Гагкаева Т.Ю., Дмитриев А.П., Павлюшин В.А. Микробиота зерна - показатель его качества и безопасности. Защита и карантин растений, 2012, 9: 14-18.

12. Pažoutova S., Pešicova K., Chudčkova M., Srůtka P., Kolařik M. Delimitation of cryptic species inside Claviceps purpurea. Fungal Biology, 2015, 119(1): 7-26 (doi: 10.1016/j.funbio.2014.10.003).

13. Roberts A., Beaumont C., Manzarpour A., Mantle P. Purpurolic acid: A new natural alkaloid from Claviceps purpurea (Fr.) Tul. Fungal Biology, 2016, 120(1): 104-110 (doi: 10.1016/j.funbio.2015.10.011).

14. Schardl C.L. Introduction to the toxins special issue on ergot alkaloids. Toxins, 2015, 7(10): 4232 4237 (doi: 10.3390/toxins7 104232).

15. Scott P.M. Analysis of ergot alkaloids - a review. Mycotoxin Research, 2007, 23(3): 113-121.

16. Maruo V.M., Bracarense A.P., Mйtayer J.-P., Vilarino M., Oswald I.P., Pinton P. Ergot alkaloids at doses close to EU regulatory limits induce alterations of the liver and intestine. Toxins, 2018, 10(5): 183 (doi: 10.3390/toxins10050183).

17. Mantle P.G. Comparative ergot alkaloid elaboration by selected plectenchymatic mycelia of Claviceps purpurea through sequential cycles of axenic culture and plant parasitism. Biology, 2020, 9(3): 41 (doi: 10.3390/biology9030041).

18. Oeser B., Kind S., Schurack S., Schmutzer T., Tudzynski P., Hinsch J. Cross-talk of the biotrophic pathogen Claviceps purpurea and its host Secale cereale. BMC Genomics, 2017, 18(1): 273 (doi: 10.1186/s12864-017-3619-4).

19. Pažoutová S., Olšovská J., Linka M., Kolínská R., Flieger M. Chemoraces and habitat specialization of Claviceps purpurea populations. Applied and Environmental Microbiology, 2000, 66(12): 5419-5425 (doi: 10.1128/AEM.66.12.5419-5425.2000).

20. Звонкова Е.Н., Шаин С.С., Сайбель Е.С. Пути получения нейрогормональных препаратов эргопептидного ряда. Российский химический журнал, 2005, 49(1): 125-134.

21. Miedaner, T., Dänicke S., Schmiedchen B., Wilde P., Wortmann H., Dhillon B.S., Geiger H.H., Mirdita V. Genetic variation for ergot (Claviceps purpurea) resistance and alkaloid concentrations in cytoplasmic-male sterile winter rye under pollen isolation. Euphytica, 2010, 173(3): 299-306 (doi: 10.1007/s10681-009-0083-5).

22. Mainka S., Dänicke S., Böhme H., Ueberschär K.-H., Liebert F. On the composition of ergot and the effects of feeding different ergot sources on piglets. Animal Feed Science and Technology, 2007, 139(1): 52-68 (doi: 10.1016/j.anifeedsci.2006.12.001).

23. Mirdita V., Miedaner T. Resistance to ergot in self-incompatible germplasm resources of winter rye. Journal of Phytopathology, 2009, 157(6): 350-355 (doi: 10.1111/J.1439-0434.2008.01499.X).

24. Сафонова И.В., Аниськов Н.И., Кобылянский В.Д. База данных генетических ресурсов коллекции озимой ржи ВИР как средство классификации генетического разнообразия, анализа истории коллекции и эффективного изучения и сохранения. Вавиловский журнал генетики и селекции, 2019, 23(6): 780-786 (doi: 10.18699/VJ19.552).

25. Mirdita V., Dhillon B.S., Geiger H.H., Miedaner T. Genetic variation for resistance to ergot (Claviceps purpurea [Fr.] Tul.) among full-sib families of winter rye (Secale cereale L.). Theoretical and Applied Genetics, 2008, 118(1): 85-90 (doi: 10.1007/s00122-008-0878-0).

26. Miedaner T., Mirdita V., Rodemann B., Drobeck T., Rentel D. Genetic variation of winter rye cultivars for their ergot (Claviceps purpurea) reaction tested in a field design with minimized interplot interference. Plant Breeding, 2010, 129(1): 58-62 (doi: 10.1111/j.1439-0523.2009.01646.x).

27. Sysuev V.A., Saitov V.E., Farafonov V.G., Suvorov A.N., Saitov A.V. Theoretical background of calculating of the parameters of the device for grain cleaning from ergot sclerotia. Russian Agricultural Sciences, 2017, 43(3): 273-276 (doi: 10.3103/S1068367417030156).

28. Сысуев В.А., Саитов В.Е., Фарафонов В.Г., Саитов А.В. Исследование параметров движения зерна в жидкости устройства для удаления спорыньи. Инженерные технологии и системы, 2019, 29(2): 248-264 (doi: 10.15507/2658-4123.029.201902.248-264).

29. Saitov V.E., Farafonov V.G., Saitov A.V. Experimental substantiation of the effective height of a grain falling by a stream of liquid in an ergot release device. IOP Conference Series: Earth and Environmental Science, 2019, 341: 1-6 (doi: 10.1088/1755-1315/341/1/012123).

1 ФГБНУ Федеральный аграрный научный центр Северо-Востока им. Н.В. Рудницкого, 610007 Россия, Киров, ул. Ленина, 166а,

e-mail: immunitet@fanc-sv.ru $\bowtie$, sheshegova.tatyana@yandex.ru;

2Институт биохимии и физиологии микроорганизмов

им. Г.К. Скрябина РАН - обособленное подразделение

ФГБУН ФИЦ Пущинский научный центр

биологических исследований РАН,
Поступила в редакцию 1 апреля 2021 года 


\title{
SEARCH FOR RYE AND WHEAT GENOTYPES \\ WHICH ARE RESISTANT TO Claviceps purpurea (Fr.) Tul. AND HAMPER ACCUMULATION OF ERGOALKALOIDS IN SCLEROTIA
}

\author{
T.K. Sheshegova ${ }^{\boxplus}$, L.M. Shchekleina ${ }^{1}$, T.V. Antipova ${ }^{2}$, V.P. Zhelifonova ${ }^{2}$, A.G. Kozlovskiy ${ }^{2}$
}

1Rudnitsky Federal Agricultural Research Center of the North-East, 166a, ul. Lenina, Kirov, 610007 Russia, e-mail immunitet@fanc-sv.ru (corresponding author $\bowtie$ ), sheshegova.tatyana@yandex.ru;

${ }^{2}$ Skryabin Institute of Biochemistry and Physiology of Microorganisms RAS - a separate subdivision of the Federal Research Center Pushchino Scientific Center for Biological Research RAS, 5, Prospekt Nauki, Pushchino 142290 Russia, e-mail kozlovski@ibpm.pushchino.ru, tatantip@rambler.ru, zhelifonova@yandex.ru

ORCID:

Sheshegova T.K. orcid.org/0000-0003-2371-4949

Shchekleina L.M. orcid.org/0000-0002-3589-5524

Zhelifonova V.P. orcid.org/0000-0001-9213-9584

Antipova T.V. orcid.org/0000-0002-4860-2647

The authors declare no conflict of interests

Acknowledgements:

The authors are grateful to B.P. Baskunov (Skryabin Institute of Biochemistry and Physiology of Microorganisms RAS) for the mass spectrometric data.

Received April 1, 2021

doi: 10.15389/agrobiology.2021.3.549eng

\section{Abstract}

Ergot [Claviceps purpurea (Fr.) Tul.] is a progressive disease of rye and wheat crops. Ergot alkaloids (EA) derived from the fungus can cause severe health problems in both humans and animals. Ergot-resistant cereals are the guarantors to solve the problem. Here, we aimed to determine the EA profiles and content in sclerotia of the Kirov population of $C$. purpurea and to search for rye and wheat genotypes resistant to ergot and with no EA accumulation to be used as sources of these traits in breeding. One hundred varieties of winter rye (Secale cereale L.) and spring soft wheat (Triticum aestivum L.) obtained from the collection of the Vavilov All-Russian Institute of Plant Genetic Resources (VIR) and bred at the Rudnitsky Federal Agricultural Research Center of the North-East were tested in 2017-2019 for ergot resistance by artificial inoculation of flowers with a suspension of $C$. purpurea conidia $\left(3 \times 10^{6} / \mathrm{ml}\right)$. EA profiles and amount were estimated by thin layer chromatography on silica gel plates (Silica gel F254, Merck, Germany). The metabolites were identified by co-chromatography with standards and by UV spectra (a UV-160A spectrophotometer, Shimadzu, Japan) and mass spectra (an LCQ Advantage MAX spectrometer, Thermo Finnigan, Germany). Most of the tested samples were susceptible to ergot. In wheat, only two varieties were immune (Novosibirskaya 18 and a new line T-66) and 13 varieties were relatively resistant with a lesion level of no more than $5.2 \%$ and a sclerotia content in grain of no more than $0.3 \%$ vs. $21.7 \%$ and $1.5 \%$ in the most susceptible (indicator) variety. In winter rye, immune forms were absent, in 10 varieties, the lesion varied from $5.8 \%$ to $33.0 \%$ and sclerotia contamination of grain from $0.3 \%$ to $1.4 \%$ vs. $100 \%$ and $37.0 \%$ in the indicator) variety). The immune and least affected varieties of rye and wheat can be used in breeding programs as genetic sources for the trait. The EA composition and amount in the fungus C. purpurea sclerotia were analyzed in 30 varieties of rye and wheat with different susceptibility to ergot. The EA composition was the same and consisted of ergocristine, ergotamine, and its stereoisomer ergotaminine. Only in the Kazakh wheat variety Samgau, we identified one EA, the ergotamine. The amount of EA in sclerotia varied from $0 \%$ to $0.36 \%$ of their weight for rye plants and from 0 to $2.40 \%$ for wheat plants. Nine new rye populations bred at the at the Rudnitsky Federal Agricultural Research Center of the North-East and four wheat varieties do not accumulate EA. A weak negative relationship was found between the weight of a sclerotium and the EA accumulation, $r=-0.46(\mathrm{p}=0.05)$ for winter rye and $r=-0.32(\mathrm{p}=0.05)$ for spring wheat. The revealed tendency increases the biological hazard of the small and most difficult to separate fraction of sclerotia in the grain mass. No significant relationship was found between the toxicity and pathogenicity of the fungus $C$. purpurea as evidenced by the correlation between the ergot occurrence and the EA content in the rye $(r=0.22, \mathrm{p}=0.05)$. Nevertheless, data on the EA level are important for the search for immunologically and breeding-valuable genotypes that combine resistance to ergot and no EA accumulation. This trait is characteristic of the German wheat variety Epos and the new rye populations Rumba, Harmony, and Symphony.

Keywords: winter rye, spring wheat, ergot, Claviceps purpurea, sclerotia, resistant cultivars, ergo alkaloids, toxicity, pathogenicity. 